\title{
Behandeling en stigmamanagement bij opzettelijke zelfverwonding
}

Het smalle pad tussen te veel en te weinig interveniëren

- Opzettelijke zelfverwonding wordt gedefinieerd als de intentionele directe beschadiging van het eigen lichaam, zonder bewuste suïcidale intentie. De behandeling varieert van gedwongen opname in een psychiatrische instelling (in het Britse Gemenebest), tot een permissieve aanpak zonder behandeling en uiteenlopende behandelingsmogelijkheden er tussenin. Eerst wordt de gepastheid van de mate van interveniëren besproken in functie van verschillende diagnosen. Het tweede gedeelte van het artikel bespreekt het advies dat door hulpverleners verstrekt wordt aangaande de omgang met wonden en littekens en aangaande de mogelijkheden voor een (gewezen) zelfverwonder om het stigma van een deviante identiteit te vermijden. Een rondvraag bij Belgische hulpverleners bracht aan het licht dat velen onder hen adviseren om littekens te verbergen, terwijl er anderzijds aanwijzingen zijn dat niet-verbergen een teken van herstel is. Aangezien verbergen en smoesjes verzinnen ook kunnen leiden tot de instandhouding van een deviante identiteit, wordt gewezen op meer gepaste vormen van stigmamanagement.

\section{Inleiding}

Opzettelijke zelfverwonding wordt gedefinieerd als de intentionele beschadiging van het eigen lichaamsweefsel, zonder bewuste suïcidale motivatie (Klonsky, 2007) en zonder cultureel aanvaarde rituele of esthetische oogmer-

I. VAN CAMP is licentiaat in de psychologie en behaalde een postgraduaat getuigschrift counseling vanuit psychoanalytisch perspectief aan de Universiteit Gent. Momenteel bereidt zij aan de vakgroep Psychoanalyse en Raadplegingspsychologie een empirisch doctoraatsproefschrift voor over opzettelijke zelfverwonding. E-mail: ingrid.vancamp@ugent.be. 
ken (Favazza, 1996). Zelfverwonding kan optreden als geassocieerd fenomeen bij verschillende psychopathologische aandoeningen, maar ook in afwezigheid daarvan (Crowe \& Bunclarck, 2000; Hodgson, 2004). De laatste decennia merkt men een algemene toename in de prevalentie en een duidelijke introductie ervan in de ambulante praktijk (Verhaeghe, 2009). Vaak weet de hulpverlener echter niet hoe hij of zij op de zelfverwonding moet reageren en staat deze hulpverlening haaks op de behoeften en verwachtingen van de patiënt. Er bestaan ook belangrijke verschillen in de mate van interveniëren, vooral wanneer men de psychotherapeutische praktijken wereldwijd vergelijkt. Daarnaast bestaan er belangrijke verschillen in het advies dat gegeven wordt omtrent stigmamanagement; het omgaan met wonden en littekens die het gevolg zijn van zelfverwonding. Het uiteenlopende van deze interventies onderstreept de noodzaak om middenweg tussen te veel en te weinig interveniëren te vinden, waarbij rekening wordt gehouden met de visie van ervaringsdeskundigen.

Als voorbeelden van repressieve interventiemogelijkheden worden hospitalisatie en antizelfverwondingscontracten besproken, met hun toepassingsmogelijkheden en contra-indicaties. Hier tegenover staat het niet-interveniëren waarbij de zelfverwonding genegeerd wordt als zijnde aandachttrekkerij. Uit de literatuur blijkt echter dat de motivatie voor zelfverwonding geen aandachttrekkerij is, maar een manier om met ondraaglijke emoties om te gaan. Dit is evenzeer het geval bij zelfverwonding in penitentiaire instellingen, als bij kopieergedrag in scholen of psychiatrische instellingen. Telkens kan men de zelfverwonding als een signaal voor psychisch lijden beschouwen. Deze signaalfunctie suggereert dat de focus van het therapeutisch handelen zich niet dient te richten op de zelfverwonding op zich, maar dat er steeds een aanpak van de onderliggende problematiek nodig is.

In het tweede deel van dit artikel wordt op basis van de literatuur, gesprekken met hulpverleners en citaten van patiënten, het te veel en te weinig interveniëren op gebied van stigma-management besproken. Welk advies kan de hulpverlener aan de patiënt geven, wat betreft omgaan met wonden en littekens door middel van verbergen, cover-stories en het geven van een verantwoording, om het stigma van een deviante identiteit te vermijden (Hodgson, 2004)?

\section{Indicaties en contra-indicaties voor hospitalisatie}

Bij de behandeling van opzettelijke zelfverwonding kan de mate van interveniëren sterk variëren. De meest restrictieve vorm van interveniëren is het beperken van de gedragsvrijheid van de zelfverwonder, door hem of haar te hospitaliseren in de Psychiatrische Afdeling van een Algemeen Ziekenhuis (PAAZ) of in een psychiatrische instelling. In België gebeurt dit alleen wanneer de onderliggende diagnose of de comorbiditeit daar aanleiding toe geeft. Dit is het geval bij zelfverwonding ten gevolge van zware depressie (Tanghe \& De Winter, 2004) of bij zelfverwonding gekoppeld aan suïcidaliteit. Een andere reden tot hospitalisatie is een risico op automutilatie of 
zware zelfverminking. Deze termen zijn voorbehouden voor ernstige verminkende vormen van zelfverwonding, zoals de amputatie van een lidmaat, enucleatie of zelfcastratie (Vandereycken, 2010). Deze ernstige vormen zijn zeldzaam, gebeuren meestal eenmalig en beperken zich in de regel tot patiënten met een psychose of acute intoxicatie (Favazza, 1996). Dit geldt ook voor de couranter voorkomende zelfimmolatie.

Omwille van de ernst en blijvende gevolgen van automutilatie, is preventie het sleutelwoord. Een gemakkelijk observeerbare voorbode van een naderende zware zelfverminking bij patiënten met een acute psychose is een zelfgekozen verandering van het uiterlijk, zoals zichzelf kaal scheren of ernstig haar uitplukken (Favazza, 1996). Van Erven (1998) wijst erop dat de alertheid op de kleinste aanwijzingen in het gedrag en de verbale uitingen van een psychoticus die in de richting van automutilatie wijzen ernstig moeten genomen worden, maar dat een dergelijke alertheid slechts gedurende beperkte tijd mogelijk is. Dit heeft tot gevolg dat men in de praktijk voor ten minste een gedeelte van de dag aangewezen zal zijn op verregaande vrijheids- en bewegingsbeperkingen of sedatie. Doordat deze maatregelen bij de psychotische patiënt op onbegrip stuiten, kunnen ze echter onrust, angst en agressie oproepen, wat uiteraard niet bevorderlijk is voor het genezingsproces. Daarom zal een effectieve interventie ook steeds dienen te bestaan uit het couperen van de onderliggende psychose.

Een vergelijkbaar probleem doet zich voor bij de behandeling van zelfverwonding bij personen met een mentale achterstand en bij neurologische of somatische aandoeningen, zoals onder meer het geval is bij het syndroom van Lesch-Nyhan, het syndroom van Rett of fenylketonurie (Verhoeven \& Tuinier, 1998). Daarbij bestaat de zelfverwonding voornamelijk uit het zichzelf slaan, stoten, stompen en schoppen, bonken, bijten en krabben. Deze vormen zijn veelal stereotiep van aard of gaan met stereotiep gedrag gepaard. Omwille van het lichamelijk letsel dat hierbij kan worden opgelopen, zijn beschermende interveniërende maatregelen aangewezen, te meer daar de opzettelijkheid van het zelfverwondend gedrag bij personen met een ernstige mentale handicap ter discussie staat (Haveman \& Reijnders, 1998). In de genoemde gevallen is de noodzaak om tot een interventie buiten de wil van de patiënt over te gaan, vrij onomstreden; dit staat echter in schril contrast met de situatie in de Britse Gemenebest.

Volgens de UK Mental Health Act is opzettelijke zelfverwonding, zowel in Groot-Brittannië (Tantam \& Whittaker, 1992) als in Australië (Cumming e.a., 2006), op zichzelf voldoende reden voor gedwongen opname, omdat het onder de noemer valt van deliberate self-harm. In de Britse onderzoekstraditie omvat dit elk opzettelijk zelfverwondend gedrag, zonder te kijken naar de intentie waarmee dit gedrag gepleegd werd. Hierdoor staat elke zelfverwonding dus gelijk aan een suïcidepoging, waarvoor in de landen van het Britse Gemenebest een gedwongen opname in een psychiatrische instelling wordt opgelegd. Dit wordt treffend beschreven door de Britse Pembroke (2001) en de Australische Leatham (2005); beiden intelligente en vrij goed functionerende vrouwen die gedwongen opgenomen werden na een occasionele incidentie van opzettelijke zelfverwonding. Ook buiten het Britse Gemenebest 
werd hospitalisatie in het verleden door bepaalde auteurs aangeraden, bijvoorbeeld voor repetitieve snijders en branders, omdat deze tot de moeilijkst effectief te behandelen patiënten zouden behoren (Favazza, 1996).

Er zijn echter belangrijke nadelen verbonden aan de al dan niet gedwongen opname van zelfverwonders zonder zware comorbiditeit. Enerzijds zijn er sociaalmaatschappelijke implicaties, vanwege de hoge kosten verbonden aan een ziekenhuisopname; anderzijds spelen de ethische kwesties van mensenrechten en zelfbeschikkingsrecht (Van Erven, 1998). Daarnaast zijn er belangrijke nadelen voor de zelfverwonder, die het herstel negatief kunnen beïnvloeden. Een van de problemen van de intramurale psychiatrie is dat de patiënten een regressief beeld kunnen vertonen, doordat ze terugvallen in een hulpeloze en afhankelijke positie die associaties kan oproepen met het eventuele invaliderende milieu uit de kindertijd. De problematiek kan zelfs zodanig toenemen, dat de patiënt zich van kwaad tot erger gaat verwonden (Draijer, 2001). Los van een eventuele voorgeschiedenis van invalidatie, vormt het leven in de afhankelijkheidspositie van een institutionele setting op zich reeds een risicofactor voor opzettelijke zelfverwonding. Onderzoek heeft aangetoond dat personen die vroeger niet aan zelfverwonding deden, daarmee kunnen beginnen wanneer ze in een situatie geplaatst worden waarin ze zich niet meer meester over hun eigen leven voelen en waar ze noodgedwongen passief moeten zijn (Smith e.a., 2004).

Een voorbeeld van dergelijke situaties zijn gevangenissen, waar zelfverwonding veelvuldig voorkomt. Dit is vooral te wijten aan problemen met het hanteren van de stress die eigen is aan het gevangenisleven, onder meer doordat men er dicht op elkaar leeft en geen controle heeft over de situatie. Bovendien beschouwen sommige gevangenen de wereld in het algemeen en de gevangenis in het bijzonder als overweldigend, onrechtvaardig en kwaadwillig arbitrair. De stress die dit veroorzaakt bereidt hun lichaam voor op een vecht- of vluchtreactie, waarvoor ze geen andere uitingsvorm ter beschikking hebben dan het aangaan van een gevecht met een andere gedetineerde - waarop meestal sancties staan - of de agressie op zichzelf te richten (Caldas e.a., 2009; Thyssen \& Van Camp, 2014). In een empirisch onderzoek in de gesloten afdeling van een Nederlands psychiatrisch ziekenhuis ontdekten Nijman en À Campo (2002) dat er een verband bestaat tussen opzettelijke zelfverwonding en naarbuiten gerichte agressie, wat suggereert dat stressgeïnduceerde agressie die niet naar anderen toe geuit kan worden, zich kan vertalen in zelfverwonding (Gratz \& Roemer, 2004).

De situatie in een psychiatrische inrichting is niet onvergelijkbaar met deze in een gevangenis. Het verhoogd voorkomen van opzettelijke zelfverwonding is hier zowel te wijten aan de psychopathologie van de patiënten als aan de beperkingen die het leven in een inrichting met zich meebrengt (Favazza, 1996); met name het gebrek aan controle over het eigen leven. Personen in een inrichting voelen zich in toenemende mate machteloos, nietgewaardeerd en buitenspel gezet - allemaal gevoelens die in verband worden gebracht met het optreden van opzettelijke zelfverwonding (Smith e.a., 2004). Zo beschrijft Van Erven (1998) een groep patiënten die zich vrijwel alleen op de psychiatrische afdeling verwondingen toebrengt en niet daar- 
buiten. Boevink en Escher (2001, p. 76) citeren een patiënte die vertelt over haar gedrag: 'Tijdens opnames ging ik me meer beschadigen (...). Niet om te laten zien dat het erg was met mij, want ik vertelde het meestal niet, om daar te kunnen overleven.'

Zelfverwondend gedrag kan ook aanstekelijk werken voor anderen, waardoor het epidemische vormen kan gaan aannemen, vooral in repressieve settingen zoals gevangenissen en gesloten psychiatrische afdelingen (Broers \& De Lange, 1998). Hierbij gaan sommige geïnstitutionaliseerde personen het zelfverwondend gedrag van anderen overnemen, terwijl ze dat voordien niet deden. Volgens Draijer (2001) is dit te wijten vaan de belonende waarde ervan, zonder dat de motieven ervoor bewust beleefd hoeven te worden. Het kan een vorm van communicatie zijn die wordt overgenomen, omdat deze het best uitdrukt hoe men zich van binnen voelt of het voegt bijvoorbeeld iets toe aan de dramatiek in de presentatie van de klachten, waardoor het uitdrukking geeft aan het gevoel van wanhoop over zichzelf. Epidemiciteit treedt soms ook op in scholen. Jongeren die het al moeilijk hebben, kunnen bij het zien van sporen van zelfverwonding dit gedrag gaan overnemen, net zoals dit het geval is in institutionele situaties. Anderzijds wijst Callens (2007) erop dat het niet zo is dat gelukkige jongeren die goed in hun vel zitten, plots met zelfverwondend gedrag zullen beginnen omdat ze dit bij anderen hebben opgemerkt.

Omwille van de nadelen van hospitalisatie pleit Ingenhoven (1998, p. 72) ervoor dat zelfs bij een vrijwillige opname de aandacht vooral dient te gaan naar 'het stellen van concrete haalbare doelen, zoals het behandelen van suïcidaliteit, detoxificatie, het onder controle brengen van randpsychotische symptomen, nadere diagnostiek en psycho-educatie, het instellen op medicatie, het organiseren van een psychotherapeutische vervolgbehandeling en het interveniëren in de thuissituatie of het steunsysteem, (waarbij) de autonomie van de patiënt maximaal dient gerespecteerd te worden'.

\section{Antizelfverwondingscontract}

Een tweede interventiemethode die zich aan het repressieve uiteinde van het interventiespectrum bevindt en die zowel in de intramurale als de ambulante zorg gebruikt kan worden, is het antizelfverwondingscontract. Hierbij dient de patiënt een contract te ondertekenen dat hij of zij zich tijdens de behandeling niet zal verwonden, op straffe van sancties of zelfs uitsluiting van de therapie. Het programma Self-Abuse Finally Ends (SAFE) is hiervan een voorbeeld. SAFE werd in 1985 opgericht door Karen Conterio en Wendy Lader - twee pioniers op gebied van empirisch onderzoek rond opzettelijke zelfverwonding - als de eerste ondersteuningsgroep voor poliklinische patiënten in de Verenigde Staten (Conterio \& Lader, 1998). Het programma omvat zowel individuele therapie als groepstherapie en schrijfopdrachten om patiënten te leren hun communicatievaardigheden te ontwikkelen en gevoelens te verbaliseren. Er wordt van de patiënten vereist dat ze een antizelfverwondingscontract ondertekenen. Bij het verbreken hiervan worden 
ze op voorwaardelijke proeftijd gezet. Een groot percentage van de personen die het SAFE-programma tot het einde toe volhouden, blijken niet meer terug te vallen in zelfverwondend gedrag. Een aanzienlijk aantal patiënten verlaat het programma echter voortijdig (Strong, 1998), wat wellicht te wijten is aan de moeilijkheidsgraad ervan.

Ook dialectische gedragstherapie werkt met een contract, waarin gesteld wordt dat de therapeut na een incidentie van niet-medisch-urgente zelfverwonding gedurende 24 uur geen (telefonisch) contact mag hebben met de patiënt (Linehan, 2002).

Er zijn meerdere nadelen aan het werken met een antizelfverwondingscontract. Het streven naar een absoluut verdwijnen van de zelfverwonding kan bij elke terugval een gevoel van falen veroorzaken bij de patiënt. Dit roept spanning op, die vervolgens de drang om zichzelf te verwonden verhoogt. Door het repressieve karakter van de contracten is de kans bovendien groot dat het zelfverwondend gedrag vervangen wordt door andere, al dan niet sociaal meer geaccepteerde vormen van zelfbeschadigend gedrag, zoals vreetbuien (al dan niet gevolgd door braken, alcohol- en middelenmisbruik) of risicozoekend gedrag (Chapman e.a., 2006; Tanghe \& De Winter, 2004). Trachten om zelfverwondend gedrag uit te doven voordat de onderliggende problematiek is aangepakt, houdt daarnaast nog meerdere gevaren in. Zo kan het risico op naar buiten gerichte agressie toenemen (Gratz \& Roemer, 2004; Levenkron, 1998), kan het onderdrukte zelfverwondende gedrag zich gaan uiten in een toestand van dissociatie of tijdens de slaap (bijvoorbeeld tot bloedens toe krabben) of kan de patiënt overstappen op minder zichtbare vormen van zelfverwonding (Broers \& De Lange, 1998).

Een bijkomend gevaar is gekoppeld aan het gegeven dat veel zelfverwonders geen hulp zoeken voor hun zelfverwondend gedrag op zich - omdat ze dit zien als een oplossing voor hun ondraaglijk lijden (Hodgson, 2004) maar zich wel tot de hulpverlening richten, juist omwille van dit onderliggende psychisch lijden. Wanneer ze zich dan niet houden aan een opgelegd antizelfverwondingscontract, kunnen ze uitgesloten worden van het therapeutisch programma en op die manier de toegang verliezen tot de voor hen vaak levensnoodzakelijke hulp. Ervaringsdeskundige Victoria Leatham (2005) beschrijft haar hopeloosheid, toen het haar na een voorval van opzettelijke zelfverwonding verboden werd nog langer in opname te blijven vanwege haar 'recalcitrante' houding, en zij naar huis werd gezonden terwijl ze in de overtuiging verkeerde dat ze het daar niet zou redden.

Wanneer het ondertekenen van een antizelfverwondingscontract optioneel is, kan dit wel een bruikbaar hulpmiddel zijn, aangezien 'zelfverwondend gedrag zonder de medewerking van de patiënt nooit structureel te veranderen is' (Van Erven, 1998, p. 118). Het mag echter nooit gebruikt worden als een pressiemiddel waarmee noodzakelijke behandeling ontzegd kan worden. Hierdoor kan immers het suïciderisico toenemen, aangezien opzettelijke zelfverwonding kan dienen als een vervanging of compromis voor de drang om zelfmoord te plegen (Klonsky, 2007). Hoewel het sluiten van antizelfverwondingscontracten dus meestal een weinig effectieve en potentieel gevaarlijke praktijk is, is het wel nodig om grenzen te stellen aan zelfver- 
wondend gedrag. Een voorbeeld van begrenzing is het verbod om zichzelf te verwonden tijdens een therapiesessie voor de ogen van de therapeut, zoals geillustreerd in een gevalstudie van Samuel Markey (2006).

\section{Het probleem met niet-interveniëren}

Aan het andere uiteinde van het interventiespectrum bij opzettelijke zelfverwonding staat niet-interveniëren. Opzettelijke zelfverwonding wordt dan gezien als aandachttrekkerij, waarop men probeert dit gedrag uit te doven door het te negeren. Los van het gegeven dat negeren niet helpt, zijn er vanuit verschillende invalshoeken redenen aan te voeren waarom het therapeutisch onverantwoord is. Empirisch onderzoek bij jongeren heeft aangetoond dat aandachttrekkerij zelden een rol speelt en dat een manipulatieve functie een te verwaarlozen prevalentie heeft (Klonsky, 2007). Meestal wordt de zelfverwonding immers angstvallig geheim gehouden (Nock, 2008; Smith e. a., 2004; Verhaeghe, 1999). Een aanzienlijk aantal studies toonde bovendien aan dat de voornaamste functie affectregulatie is. Opzettelijke zelfverwonding helpt om aan emoties te ontsnappen of te ontkomen in de vorm van experiential avoidance (Chapman e.a., 2006; Van Camp, 2012). Het kan ook helpen om emoties te beheersen of reguleren (Gratz e.a., 2002). Daarnaast kan opzettelijke zelfverwonding de functie hebben om het negatieve affect dat als ondraaglijk en onvermijdelijk wordt gepercipieerd te verminderen, te blokkeren of er zich van af te leiden (Milligan \& Andrews, 2005). Deze affectregulatie omhelst dus een verscheidenheid van functies, zoals het uitdrukken van woede en het herwinnen van normale gevoelens (Brown e.a., 2002), het onder controle houden van angsten, weghouden van pijnlijke herinneringen, gevoelens van spanning, ondraaglijke leegte of psychische pijn (Draijer, 2001) of het herwinnen van zelfcontrole (Favazza, 1996).

Een populatie waar het aandeel van manipulatieve zelfverwonding zeer overschat wordt, zijn gedetineerden. Onderzoek in gevangenissen toonde aan dat men op basis van het type wond een onderscheid kan maken tussen gevangenen die zich verwonden omwille van de affectregulerende functie en gevangenen met een manipulatief oogmerk. Verwondingen die gevangenen uit woede aanbrengen, bestaan meestal uit twee tot vier diepe sneden in het vlezige gedeelte van de armen of benen, waarvoor geen behandeling werd gezocht. De gevangenen die daarentegen met hun daad een speciale behandeling trachten te verkrijgen, maken slechts een enkele kleine snede die ze wel laten hechten (Favazza, 1996). Hieruit blijkt dat het in penitentiaire instellingen wel kan voorkomen dat men zich doelbewust verwondt, om bepaalde voordelen te verkrijgen (zoals overplaatsing naar de medische vleugel of een isoleercel), maar dat de voornaamste functie het omgaan met ondraaglijke negatieve emoties is (Caldas e.a., 2009).

Een groep waarin soms provocatieve zelfverwonding wordt vertoond, is die van mensen met een borderlinepersoonlijkheidsstoornis (BPS). Deze personen kunnen dreigen met zelfverwonding of ze kunnen zich in het bijzijn van anderen demonstratief verwonden (Verhaeghe, 1999). Toch mag ook hier 
de zelfverwonding niet genegeerd worden, omdat ze hier verschijnt als epifenomeen van de onderliggende aandoening. BPS is een complexe psychische stoornis die gekarakteriseerd wordt door problemen met emotieregulatie en impulscontrole. De kerneigenschap is een kwetsbaar vermogen tot mentalisatie, die de neiging heeft te verdwijnen in stressvolle situaties ten gevolge van interpersoonlijke interactie (Bateman \& Fonagy, 2010), wat het provocatieve en onaangepaste sociale gedrag kan verklaren. Van de personen met een BPS heeft 70-75 procent een voorgeschiedenis van minstens één episode van opzettelijke zelfverwonding (Linehan, 2002). Dit is mogelijk te verklaren doordat zelfverwonding de emoties kan helpen reguleren en adequate emotieregulatie een kernprobleem is van BPS.

Het niet-interveniëren vanuit een onterecht minimaliseren van de ernst van de psychische problematiek die aan opzettelijke zelfverwonding verbonden is, leidt er in elke doelgroep toe dat de persoon in kwestie op zichzelf aangewezen blijft. De gevaren hiervan zijn reëel, aangezien het aantal suïciden bij borderlinepersoonlijkheidsstoornis op 9 procent geschat wordt (Linehan, 2002) en dit een van de grootste groepen mensen is bij wie zelfverwonding voorkomt. Het zichzelf verwonden kan soms ook een soort van 'oefenen' zijn voor een uiteindelijke suïcide en drempelverlagend werken. Daarom is het belangrijk de zelfverwonding als een signaal voor psychische problematiek te beschouwen. Dit biedt de mogelijkheid tot therapeutische actie, waarbij de onderliggende problemen worden aangepakt en de zelfverwonding op termijn uit zichzelf kan uitdoven.

Een andere vorm van niet-interveniëren bestaat uit een te permissieve houding ten opzichte van zelfverwonding. Het Britse National Self-Harm Network, dat voorstander is van een cliëntgeoriënteerde aanpak van opzettelijke zelfverwonding, stelt bijvoorbeeld dat de noodzaak tot zelfverwonding als een legitieme overlevingsstrategie geaccepteerd moet worden, totdat affectregulatie op een andere manier mogelijk is. Volgens dit netwerk is volledig stoppen met zelfverwonding niet de enige maatstaf voor herstel, maar kan herstel ook betekenen dat men leert leven met blijvende en complexe problemen waarvoor men meerdere coping-strategieën ontwikkelt, waarvan zelfverwonding er een kan zijn (Pembroke, 2001). Uit deze visie blijkt duidelijk de reserve ten opzichte van het willen opgeven van zelfverwonding en de twijfel in de mogelijkheid ervan. Hoewel zelfverwonding een duidelijke functie kan hebben tijdens het psychische-ziekteproces is het volgens mij onaanvaardbaar als beoogd eindpunt van een therapie, omdat dit de toepassing van alternatieve affectregulatiemogelijkheden belemmert, zoals het bewust ervaren en aanvaarden van emoties (Linehan, 2002), affectregulatie door mentalisatie (Bateman \& Fonagy, 2010) en door het aanwenden van interpersoonlijke relaties en communicatie met anderen (Vanheule e.a., 2011; Verhaeghe, 2007). Zoals in de volgende paragrafen wordt besproken, heeft het leven met open wonden belangrijke gevolgen voor het zelfgevoel en het contact met anderen. Daarom moet leven zonder zelfverwonding het uiteindelijke doel blijven van een psychotherapie die de middenweg bewandelt tussen te veel en te weinig interveniëren. 


\section{Stigmamanagement na opzettelijke zelfverwonding}

Los van dit uiteindelijke doel, moeten zelfverwonders voor zichzelf beslissen in hoeverre ze met hun gedrag naar buiten komen, om te vermijden dat ze als afwijkend worden bestempeld. Dit heeft voornamelijk betrekking op de wonden en littekens die het gevolg zijn van opzettelijke zelfverwonding. Dit wordt stigmamanagement genoemd en omvat het verbergen van wonden en littekens, het verzinnen van cover stories (zoals: 'Het was een ongelukje', of: 'De kat heeft me gekrabd') en verklaringen die een rechtvaardiging geven voor het zelfverwondend gedrag, wanneer het toch wordt ontdekt (Hodgson, 2004).

De meeste zelfverwonders beginnen met verbergen, zoals blijkt uit diverse getuigenissen van patiënten, geciteerd door Boevink en Escher (2001): 'Ik heb jarenlang mijn mouwen niet opgerold, als ik ging afwassen' (p. 19), 'Het is opvallend dat ik in de winter de grens van zelfbeschadigen sneller overschrijd dan in de zomer. In de winter kan ik alles onder kleren verbergen' (p. 77). Ook Callens (2007, p. 39) citeert een treffende getuigenis: 'Wonden tonen was voor mij nog erger dan naakt voor iemand staan. Naakt voor iemand staan is gewoon je naakte lichaam tonen, je wonden tonen is je naakte ziel tonen.'

Verbergen is ook wat door de meeste hulpverleners wordt aangeraden. Zo beveelt Ingenhoven (1998) een camouflagecursus bij een schoonheidsspecialist aan of verwijst na een 'krasvrije periode' naar een plastisch chirurg. In de praktijk blijkt plastische chirurgie echter een weinig effectieve oplossing, waarbij doorgaans het ene litteken door een ander vervangen wordt. Uit een beperkte rondvraag van de auteur en Steffi Vertriest (2013) bij hulpverleners in Vlaanderen viel op dat verbergen als noodzakelijk wordt geacht door zowel huisartsen, psychotherapeuten, psychoanalytici als psychiaters. Dit is eveneens het geval bij arbeidsgeneesheren (bedrijfsartsen), onder het motto 'uw collega's zijn uw vrienden niet', dus houd uw privéleven voor uzelf.

Naast de duidelijke voordelen van 'verbergen', zoals het vermijden van een label en stigmatisering, houdt het echter ook een aantal gevaren in. Het verbergen van de opzettelijke zelfverwonding maakt dat deze onbespreekbaar blijft voor de naaste omgeving. Het dwingt de persoon ook tot het aannemen van een alternatieve - en dus dubbele - identiteit (Hodgson, 2004) en beperkt de persoon in het deelnemen aan activiteiten waarbij het niet mogelijk is de littekens verborgen te houden (zoals zwemmen, zonnebaden en bepaalde sporten).

Cover stories of smoesjes kunnen zowel betrekking hebben op wonden of littekens die ontdekt worden, als op het bedekken van lichaamsdelen in een situatie waarbij dit ongepast is (zoals aan het strand of bij hoge temperaturen). Dikwijls zijn deze smoesjes ongeloofwaardig, maar worden ze toch geloofd. Volgens een door Hodgson (2004) geïnterviewde patiënte komt dit vooral doordat de omgeving de smoesjes wil geloven om niet met de waarheid geconfronteerd te hoeven worden. Wanneer littekens later bij toeval toch ontdekt worden, leiden eerder verzonnen smoesjes tot een verlies aan integriteit. 
Sommige personen staan zelf ook ambivalent tegenover het verzinnen van smoesjes, omdat deze dikwijls dwaas overkomen, zoals in het door Hodgson vermelde voorbeeld: 'Ik was op safari en werd aangevallen door een tijger', of, in het voorbeeld van een ex-zelfverwondster op kantoor: 'Ik draag altijd een vestje in de zomer, anders blijven mijn armen aan het papier plakken van het zweet' (Vertriest, 2013). Zowel uit de literatuur (o.a. Hodgson, 2004) als uit eigen observaties komt naar voren dat er op een gegeven moment vaak een vorm van humor in de smoesjes sluipt, al is dit soms een sarcastische vorm van humor, die mogelijk wijst op een hernieuwd gevoel van invalidatie dat de zelfverwonder ondervindt als gevolg van het moeten aannemen van een dubbele identiteit. Deze mogelijkheid zou verder empirisch onderzocht kunnen worden en het is zeker iets waaraan de hulpverlener aandacht dient te besteden.

Hoewel 95 procent van de door Hodgson (2004) onderzochte zelfverwonders er aanvankelijk voor kiest om wonden en littekens te verbergen, is dit moeilijk voor onbeperkte tijd vol te houden. Sommige personen, voor wie de zelfverwonding tot het verleden behoort, willen deze periode in hun leven graag achter zich laten. Dit wordt bemoeilijkt door het ongewone gedrag dat ze moeten vertonen om te blijven 'verbergen'. Nienke Kool, psychiatrisch verpleegkundige die werkt met zelfverwonders, merkt op dat met korte mouwen durven lopen voor veel patiënten een belangrijke stap in het herstel is (Kool, 2011). Ook de Nederlandse patiëntenvereniging Landelijke Stichting Zelfbeschadiging (LSZ; zie www.zelfbeschadiging.nl) geeft aan dat de meeste, zowel Nederlandse als Belgische, zelfverwonders waarmee de stichting in contact komt aanvankelijk hun wonden verbergen, maar later eventueel leren er meer open over te zijn.

Mensen die nog aan zelfverwonding doen verbergen de littekens vaak, terwijl mensen die gestopt zijn erover kunnen praten en ze niet meer zo snel verbergen. Uit een e-mailinterview met de LSZ van de auteur en Vertriest (2013) bleek dat de ervaringsdeskundigen die deze stichting leiden dit dapper vinden. Wanneer de zelfverwonding uiteindelijk onthuld wordt doordat de persoon erover vertelt tegen familie of goede vrienden en geleidelijk aan stopt met 'verbergen', gaat dit vaak gepaard met het geven van een verklaring of verantwoording (Hodgson, 2004), om verdere vragen vanuit de omgeving in de mate van het mogelijke te counteren. Als antwoord op mogelijke vragen stelt Levenkron (1998, p. 242) voor te zeggen: 'Dit zijn littekens uit een zeer pijnlijke periode in mijn leven. Ik ben dankbaar dat ze tot het verleden behoren' (eigen vertaling). Voor andere personen kunnen de littekens hen op het rechte pad houden, als stille getuigen van een situatie waarnaar men liefst niet terugkeert (Strong, 1998).

De schaamte die de meeste zelfverwonders over hun littekens voelen en het gegeven dat ze deze over het algemeen trachten te verbergen, weerlegt nogmaals de reeds besproken opvatting als zou opzettelijke zelfverwonding enkel een kwestie van aandachttrekkerij zijn. Anderzijds is het menig hulpverlener reeds overkomen dat wonden en littekens soms vrijuit getoond worden en als het ware aan de therapeut worden opgedrongen (Verhaeghe, 1999). Dit is volgens mij te wijten aan de bijzondere status van de hulpverle- 
ner: deze is de persoon aan wie patiënten over hun psychische problemen dienen te vertellen. De ernst van de psychische pijn kan echter soms moeilijk verwoord worden, terwijl de wonden of littekens wel iets communiceren: namelijk dat de pijn zo ondraaglijk was, dat zichzelf verwonden de enige manier was om te overleven. De zelfverwonding fungeert hier als 'taal voor het onuitspreekbare' (Lefèvre, geciteerd in Broers \& De Lange, 1998, p. 6).

Mijn eigen opvatting over stigmamanagement is dat men open wonden en korsten het beste zoveel mogelijk voor de buitenwereld verborgen houdt, omdat deze zeer zichtbaar zijn en choquerend voor de omgeving, die niet weet wat ze ervan moet denken. Wanneer een litteken zich gevormd heeft, is het aan de persoon in kwestie om na te gaan in hoeverre hij of zij zich er comfortabel mee voelt om met onbedekte littekens rond te lopen - wat in de praktijk meestal neerkomt op: met korte mouwen. Dit komt volgens de Nederlandse Stichting Zelfbeschadiging overeen met de praktijk, omdat mensen die witte littekens hebben ze minder vaak verbergen dan 'roodgloeiende littekens' (Vertriest, 2013, p. 62).

Dit niet langer verbergen staat echter niet gelijk aan het tonen van de littekens, omdat er meestal enige tijd verloopt voor deze daadwerkelijk door de omgeving worden opgemerkt. Bovendien is het een kwestie die tot het domein van de persoonlijke vrijheid behoort, net zoals het al dan niet bedekken van een operatielitteken of een tatoeage. Als hulpverlener kan men niet reageren tegen werkgevers die van hun personeel vragen een litteken of een tatoeage te bedekken. Dit kan zowel een goedbedoelde raad zijn als een vereiste die door de job gesteld wordt.

Voor het advies dat hulpverleners zelf aan hun patiënten verstrekken, stel ik voorop dit zoveel mogelijk aan de keuze van de patiënt over te laten. Men kan patiënten wel voorbereiden op reacties van de omgeving door hen, in navolging van Levenkron (1998), van een standaardzin te voorzien waarmee reacties van anderen hanteerbaar kunnen worden gehouden. De naasten en de omgeving van zelfverwonders zou ik vooral willen oproepen om hen niet te (ver)oordelen. Er is moed voor nodig om zichzelf bloot te geven en, aansluitend bij de Nederlandse visies, ben ik ervan overtuigd dat het een belangrijke stap is op weg naar herstel.

\section{Tot besluit}

Opzettelijke zelfverwonding is een signaal van psychisch lijden. Bij de behandeling ervan is het belangrijk zich te focussen op de onderliggende problematiek, zonder een te repressieve of te permissieve houding tegenover de patiënt aan te nemen, wat betreft het al dan niet stoppen met zichzelf te verwonden. Dit geldt ook voor het advies dat gegeven wordt over hoe men met wonden en littekens kan omgaan. Het verzekeren van de autonomie van de patiënt hierbij, maakt dat de hulpverlener inderdaad een smal pad moet bewandelen tussen te veel en te weinig interveniëren. Het einddoel hiervan is een leven zonder zelfverwonding, waarin ruimte is voor alternatieve vormen van affectregulatie. 


\section{Literatuur}

Bateman, A. \& Fonagy, P. (2010). Mentalization based treatment for borderline personality disorder. World Psychiatry, 9, 11-15.

Boevink, W. \& Escher, S. (2001). Zelfverwonding begrijpelijk maken. Ervaringsdeskundigen, onderzoekers en therapeuten aan het woord. Bemelen: Stichting Positieve Gezondheidszorg.

Broers, E. \& Lange, J. de (1998). Hulpverlening bij zelfverwonding in de psychiatrie. Achtergronden, verpleegproces en keuzen in de zorg. Utrecht: Trimbos-instituut.

Brown, M.Z., Comtois, K.A. \& Linehan, M.M. (2002). Reasons for suicide attempts and nonsuicidal self-injury in women with borderline personality disorder. Journal of Abnormal Psychology, 111, 198-202.

Caldas, M.T., Arcoverde, R. L., Dos Santos, T.F., Lima, M.S., Macedo, L.E. \& Lima, M.C. (2009). Condutas autolesivas entre detentas da colônia penal feminina do recife. Psicologia em Estudo, 14, 575-582.

Callens, N. (2007). Zelfverwonding bij jongeren. Een gids voor leerkrachten, leerlingenbegeleiders, ouders en vrienden. Antwerpen/Apeldoorn: Garant.

Chapman, A.L., Gratz, K.L. \& Brown, M.Z.(2006). Solving the puzzle of deliberate selfharm: the experiential avoidance model. Behaviour Research and Therapy, 44, 371-394.

Conterio, K. \& Lader, W. (1998). Bodily harm: the breakthrough healing program for self-injurers. New York: Hyperion.

Crowe, M. \& Bunclarck, J. (200o). Repeated self-injury and its management. International Review of Psychiatry, 12, 48-53.

Cumming, S., Covic, T. \& Murrell, E. (2006). Deliberate self-harm: have we scratched the surface? Behaviour Change, 23, 186-199.

Draijer, N. (2001). Zelfbeschadiging: fenomenologie, achtergronden en behandeling. In W. Boevink \& S. Escher (red.), Zelfverwonding begrijpelijk maken. Ervaringsdeskundigen, onderzoekers en therapeuten aan het woord (pp. 91-103). Bemelen: Stichting Positieve Gezondheidszorg.

Erven, A.C.J.M. van (1998). Management van zelfverwondend gedrag in een psychiatrisch ziekenhuis. In P.C.C. Duker \& R. Didden (red.), Behandelingsstrategieën bij zelfverwondend gedrag (pp. 117-140). Houten/Diegem: Bohn Stafleu van Loghum.

Favazza, A.R. (1996). Bodies under siege: self-mutilation and body modification in culture and psychiatry. Londen/Baltimore/Maryland: Johns Hopkins University Press.

Gratz, K.L. \& Roemer, L. (2004). Multidimensional assessment of emotion regulation and dysregulation: development, factor structure, and initial validation of the difficulties in emotion regulation scale. Journal of Psychopathology and Behavioral Assessment, 26, 41-54.

Gratz, K.L., Conrad, S.D. \& Roemer, L. (2002). Risk factors for deliberate self-harm among college students. American Journal of Orthopsychiatry, 72, 128-140.

Haveman, M.J. \& Reijnders, R.J.H.M. (1998). Epidemiologie van zelfverwondend gedrag. In P.C.C. Duker \& R. Didden (red.), Behandelingsstrategieën bij zelfverwondend gedrag (pp. 1-26). Houten/Diegem: Bohn Stafleu van Loghum.

Hodgson, S. (2004). Cutting through the silence: a sociological construction of self-injury. Sociological Inquiry, 74, 162-179.

Ingenhoven, T.J.M. (1998). Zelfverwondend gedrag in de psychiatrie, in het bijzonder bij de borderline persoonlijkheidsstoornis. In P.C.C. Duker \& R. Didden (red.), Behandelingsstrategieën bij zelfverwondend gedrag (pp. 61-8o). Houten/Diegem: Bohn Stafleu van Loghum. 
Klonsky, E.D. (2007). The functions of deliberate self-injury: a review of the evidence. Clinical Psychology Review, 27, 226-239.

Kool, N. (2011). Communicatie en contact maken bij zelfbeschadiging vanuit het perspectief van de psychiatrisch verpleegkundige. Lezing op de Studiedag 'Snijden in eigen vlees' op 20 september 2011 te Sint-Jozef, Pittem, België.

Leatham, V. (2005). Aderlating. Over geheimen, zelfverwonding en genezing (herz. dr.). Amsterdam: Forum.

Levenkron, S. (1998). Cutting. Understanding and overcoming self-mutilation. New York/Londen: Norton.

Linehan, M.M.(2002). Dialectische gedragstherapie bij borderline persoonlijkheidsstoornis. Theorie en behandeling. Lisse: Swets and Zeitlinger.

Markey, S. (2006). Over de behandeling van aktuaalneurose: een gevalstudie. Psychoanalytische Perspectieven, 24, 379-390.

Milligan, R.J. \& Andrews, B. (2005). Suicidal and other self-harming behaviour in offender women: the role of shame, anger and childhood abuse. Legal and Criminological Psychology, 10, 13-25.

Nijman, H.L.I. \& Campo, J.M.L.G. à (2002). Situational determinants of inpatient selfharm. Suicide and Life-Threatening Behavior, 32, 167-175.

Nock, M.K. (2008). Actions speak louder than words: an elaborated theoretical model of the social functions of self-injury and other harmful behaviors. Applied and Preventive Psychology, 12, 159-168.

Pembroke, L. R. (2001). Voor onszelf opkomen. In W. Boevink \& S. Escher (red.), Zelfverwondingbegrijpelijk maken. Ervaringsdeskundigen, onderzoekers en therapeuten aan het woord (pp.11-23). Bemelen: Stichting Positieve Gezondheidszorg.

Smith, G., Cox, D. \& Saradjian, J. (2004). Vrouwen en zelfbeschadiging. Zelfverminking begrijpen, ermee omgaan, ervan herstellen (herz. dr.). Amsterdam: SWP.

Strong, M. (1998). A bright red scream. self-mutilation and the language of pain. New York: Viking.

Tanghe, A. \& Winter, E. de (2004). Biologische psychiatrie: feiten, mythes en vooroordelen. Antwerpen/ Apeldoorn: Garant.

Tantam, D. \& Whittaker, J. (1992). Personality disorder and self-wounding. British Journal of Psychiatry, 161, 451-464.

Thyssen, L.S. \& Van Camp, I. (2014). Non-suicidal self-injury in Latin-America. Salud Mental, 37 , in druk.

Van Camp, I. (2012). Heterogeniteit van het 'snijden in eigen vlees' ... en haar therapeutische implicaties. In M. Kinet (red.), Zelfverwonding. Psychodynamiek en psychotherapie (pp. 57-74). Antwerpen/Apeldoorn: Garant.

Vandereycken, W. (2010). Reactie op 'Psychodynamische visie op automutilatie bij borderline persoonlijkheidsstoornis'. Tijdschrift voor Psychiatrie, 52, 599-601.

Vanheule, S., Verhaeghe, P. \& Desmet, M. (2011). In search of a framework for the treatment of alexithymia. Psychology and Psychotherapy: Theory, Research and Practice, 84, 84-97.

Verhaeghe, P. (1999). Liefde in tijden van eenzaamheid. Drie verhandelingen over drift en verlangen. Leuven/Amersfoort: Acco.

Verhaeghe, P. (2007). Aktuaalpathologie. Hoe luisteren als het spreken niet dragend is? In M. Kinet \& W. Vanmechelen (red.), Tussen ruis en storingen ... De golflengte vinden in psychoanalytische therapie (pp. 29-46). Antwerpen/Apeldoorn: Garant.

Verhaeghe, P. (2009). Het einde van de psychotherapie. Amsterdam: De Bezige Bij. 
Verhoeven, W.M.A. \& Tuinier, S. (1998). Diagnostiek en medicamenteuze behandeling van zelfverwondend gedrag bij verstandelijk gehandicapten. In P.C.C. Duker \& R. Didden (red.), Behandelingsstrategieën bij zelfverwondend gedrag (pp. 81-10o). Houten/Diegem: Bohn Stafleu van Loghum.

Vertriest, S. (2013). Stigmamanagement na opzettelijke zelfverwonding. Een kwalitatief empirisch onderzoek (ongepubliceerde masterdissertatie). Gent: Universiteit Gent. 